Ethiopian Journal of Environmental Studies \& Management 9 (2): 197 - 208, 2016.

ISSN:1998-0507

Submitted: November 24, 2015

doi: http://dx.doi.org/10.4314/ejesm.v9i2.7

Accepted: March 08, 2016

\title{
EFFECT OF BAHIR DAR MUNICIPAL EFFLUENTS ON WATER QUALITY OF THE HEAD OF BLUE NILE RIVER
}

\author{
*ABREHET KAHSAY MEHARI, ${ }^{1}$ SHEWIT GEBREMEDHIN, ${ }^{1}$ AND BELAYNEH AYELE ${ }^{2}$ \\ ${ }^{1}$ Fisheries, Wetlands and Wildlife Management Department, Bahir Dar University, P.O. Box \\ 5501, Bahir Dar, Ethiopia \\ ${ }^{2}$ Natural Resource Management Department, Bahir Dar University, P.O. Box 5501, Bahir \\ Dar, Ethiopia
}

\begin{abstract}
The study was conducted with the main objective of determining the effect of Bahir Dar municipal effluents on water quality of the head of Blue Nile River. Physico-chemical parameters were measured at seven points, whereas aquatic macro invertebrates were sampled at six sites. A total of 6813 aquatic macro-invertebrate individuals belonging to 30 families were collected. The Shannon-Wiener diversity Index, the Hilsenhoff family-level biotic index, Family richness and percent dipterans were calculated and differed significantly among sampling sites $(p<0.05)$. Physico-chemical parameter mean values differed significantly among sampling sites $(p<0.05)$, dissolved oxygen mean value being higher at sampling site (A) and $B O D_{5}$, TDS and conductivity values being higher at (C5). $B O D_{5}$, conductivity and total alkalinity mean values were above permissible levels set for municipal effluents to be discharged to surface water. $\mathrm{DO}, \mathrm{BOD}_{5}$ and total alkalinity mean values at head of Blue Nile River were lower than WHO recommended values for drinking water. The study concludes that the Bahir Dar municipal effluents severely affected the water quality of the head of the Blue Nile River. Therefore, a municipal waste water treatment system is urgently recommended.
\end{abstract}

Key Words: Bio-monitoring, macro invertebrates, physico-chemical parameters

\section{Introduction}

Indiscriminate liquid waste discharge is a daily practice in many developing countries (UNDP, 2004). It is reported that $70 \%$ of industries in developing countries dispose their untreated waste into water bodies (UN-Water, 2009). In Ethiopia, almost all natural waters are polluted by municipal, industrial or commercial waste of both solid and liquid nature and hazardous material, the exact load of which is, however, not known. However, streams and rivers passing large cities such

*Corresponding Author: Abrehet Kahsay

Email: abrehetkahsay66@gmail.com as in Addis Ababa in Ethiopia can be described as sewer lines for domestic and industrial wastes (Samuel et al., 2007).

Waste water disposal is a serious problem in Bahir Dar town. Major institutions and industries like Bahir Dar University, Textile factory, and Bahir Dar Abattoir discharge their effluents directly into the Blue Nile River without any treatments. Furthermore, two-thirds of all households in Bahir Dar town discharge waste water into streets and flood water drainages which ultimately discharge in to 
Blue Nile River (Mekonnen, 2012). Chemical and physical assessment is widely utilized to evaluate the extent of pollution of water bodies from industrial and other sources. However, the combination of biological assessment with physico-chemical assessment is the most appropriate means of detecting effects of pollution on the aquatic systems, because it can detect cumulative physical, chemical and biological impacts of adverse activities to an aquatic system (Mandaville, 2002; US EPA, 2002; Davis et al., 2003).

In Ethiopia, macro invertebrate composition has been used as stream and rivers water quality indicator by different researchers (Berhe, 1988; Akalu, 2006; Sitotaw, 2006; Abay, 2007; Misganaw, 2007; Wosinie and Wondie, 2014).

However, the published information about using aquatic macro invertebrates to assess the effects of municipal wastes in Ethiopia is very rare. Therefore the objective of this study was to investigate the effect of the municipal effluents of Bahir Dar town on the water quality at the head of Blue Nile River using aquatic macro invertebrate as bio-indicators. We addressed the following specific questions: (1) what is the longitudinal gradient of pollution in the municipal canal effluents? (2) Do the observed water quality parameters exceed the maximum permissible levels of international standards? And if so, to what extent? And (3) To what extent is the water of the Blue Nile River affected by the effluents of Bahir Dar municipal.

\section{Study Areas}

Bahir Dar, the capital of Amhara National Regional State is situated on the southern shore of Lake Tana, the source of Blue Nile River, approximately $565 \mathrm{~km}$ northwest of Addis Ababa at an altitude of $1801 \mathrm{~m}$ a.s.l, latitude of 11038 " $\mathrm{N}$ and a longitude of 37010 " E. It is a rapidly expanding town with commercial centers, small industries and residences in all sectors of the town. The total population of Bahir Dar was in 2007 ca. 220,000 inhabitants and has a population growth rate of $6.6 \%$ per year (CSA, 2007), which is more than twice as high as the average population growth rate in Ethiopia.

At Bahir Dar town, there is one main effluents canal that starts from GudoBahir wetlands, located at the north side of the town, and discharges its effluents made up of domestic wastewater, industrial wastewater and storm water directly in to head of Blue Nile River. The water from this river is used for different purposes like drinking, livestock watering, and irrigation by downstream communities. Besides, local people grow different vegetables and some crops at the sides of this canal using the waste water.

\section{Materials and Methods Sampling}

A total of seven sampling sites: five sites from main municipal canal and two from Blue Nile River (one site upstream to effluents joining point to head of Blue Nile River and one the most downstream site, after the effluents joined to head of Blue Nile River) were selected (Klemm et al., 1990). The sampling sites were designated as $\mathrm{C} 1$ to $\mathrm{C} 5$ for main municipal canal, A for upstream and $\mathrm{R}$ for downstream sites from River (Table 1 and Fig 1). Samples were collected in August and December, 2013 and April of 2014.Two replications per site with two dipping effort was applied. 
Table 1: Description of sampling sites

\begin{tabular}{|c|c|c|c|}
\hline $\begin{array}{l}\text { Sampling } \\
\text { Site name }\end{array}$ & Coordinates & $\begin{array}{l}\text { Altitude } \\
\text { (m a.s.l) }\end{array}$ & Descriptions \\
\hline $\mathrm{A}$ & $\begin{array}{l}11^{0} 34^{\prime} 42.38^{\prime}, \mathrm{N} \\
37^{0} 2434.80^{\prime \prime} \mathrm{E}\end{array}$ & 1789 & $\begin{array}{l}\text { Head of Blue Nile River. Most } \\
\text { upstream site, located above the } \\
\text { point where the main canal } \\
\text { effluents join the river. Covered } \\
\text { with a mixed vegetation of } \\
\text { macrophytes, shrubs and large } \\
\text { trees. }\end{array}$ \\
\hline $\mathrm{C} 1$ & $\begin{array}{l}11^{0} 35^{\prime} 13.85^{\prime \prime} \mathrm{N} \\
37^{0} 23^{`} 22.65^{\prime} \mathrm{E}\end{array}$ & 1798 & $\begin{array}{l}\text { Canal with asphalt bottom. Most } \\
\text { northern located canal site, no } \\
\text { vegetation coverage. }\end{array}$ \\
\hline $\mathrm{C} 2$ & $\begin{array}{l}11^{0} 34^{`} 52.95^{`} \mathrm{~N} \\
37^{0} 23^{`} 07.56^{\prime} \mathrm{E}\end{array}$ & 1798 & $\begin{array}{l}\text { Canal with mud bottom. Second } \\
\text { most northern canal site. Few } \\
\text { dominant types of vegetations. } \\
\text { Local people grow different types } \\
\text { of vegetables. }\end{array}$ \\
\hline $\mathrm{C} 3$ & $\begin{array}{l}11^{0} 3449.14 “ \mathrm{~N} \\
37022317.72^{\prime \prime} \mathrm{E}\end{array}$ & 1797 & $\begin{array}{l}\text { Canal with mud bottom. Local } \\
\text { people grow different types of } \\
\text { vegetables }\end{array}$ \\
\hline $\mathrm{C} 4$ & $\begin{array}{l}11^{0} 34^{`} 31.38^{\prime \prime} \mathrm{N} \\
37^{0} 23^{`} 45.18^{\prime \prime} \mathrm{E}\end{array}$ & 1796 & $\begin{array}{l}\text { Canal with mud bottom. Most } \\
\text { southern canal site, at the main gate } \\
\text { of Bahir Dar University, Papyrus } \\
\text { Cyprus vegetation planted. }\end{array}$ \\
\hline $\mathrm{C} 5$ & $\begin{array}{l}11^{0} 344^{\prime} 09.95^{\prime} \mathrm{N} \\
37^{0} 24 ` 14.56^{\prime} \mathrm{E}\end{array}$ & 1797 & $\begin{array}{l}\text { This site located where the water } \\
\text { of the main municipal canal enters } \\
\text { the river. Local people grow } \\
\text { vegetables }\end{array}$ \\
\hline $\mathrm{R}$ & $\begin{array}{l}11^{0} 34 ` 03.99^{\prime \prime} \mathrm{N} \\
37^{0} 244^{`} 16.778^{` `} \mathrm{E}\end{array}$ & 1798 & $\begin{array}{l}\text { Head of Blue Nile river, most } \\
\text { downstream site }\end{array}$ \\
\hline
\end{tabular}




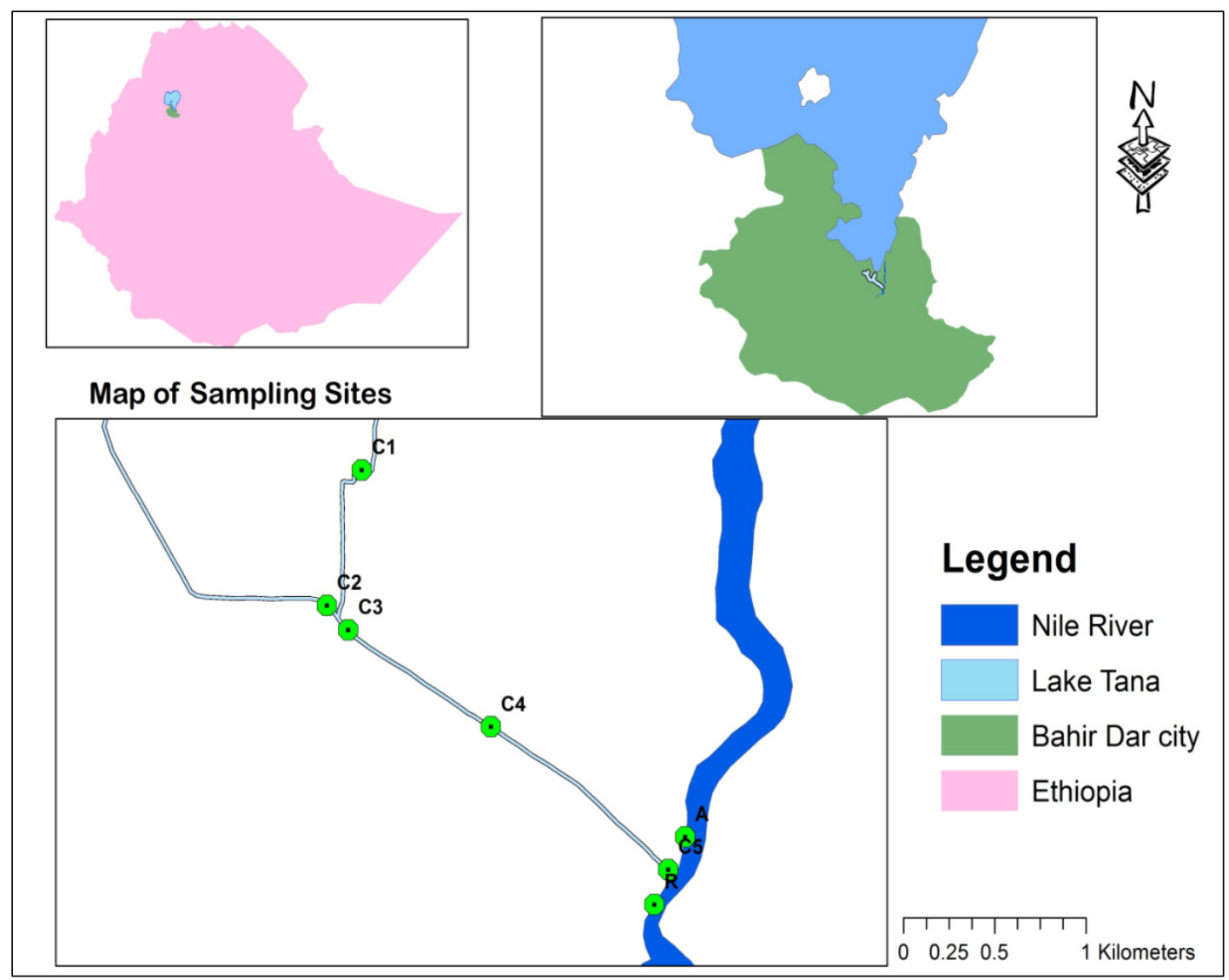

\section{Data collection}

\section{Physico-chemical Parameters}

Water temperature, dissolved oxygen (DO), $\mathrm{pH}$, total dissolved solids (TDS) and conductivity were measured in situ using YSI 556 MPS Multi-probe field meter. Water samples for laboratory analysis were collected and stored in polythene bottles that had been pre-washed with $10 \%$ nitric acid and thoroughly rinsed with de-ionized water (Jain and Bhatia, 1987). Samples for $\mathrm{BOD}_{5}$ were analyzed according to standard methods (APHA, 1998) at the laboratory of the Institute of Technology of Bahir Dar University. Total hardiness, total alkalinity and phosphate were analyzed at Amhara Design and Supervision work Enterprise laboratory using Paqualab 700 photometer. Aquatic Macro invertebrate Data

Aquatic macro-invertebrates were sampled using a D-frame net with mesh size of $500 \mu \mathrm{m}$. Next they were removed with forceps from the net and put into bottles. All samples were preserved with $70 \%$ ethanol until laboratory analysis and counting. All the organisms in the sample were enumerated and identified to the family level using a dissecting microscope and standard keys (Edmondson, 1959; Jessup et al., 1999; Gooderham and Tysrlin, 2002 and Bouchard, 2004).

\section{Data Analysis}

Descriptive statistics were used to analyze water quality data. For the aquatic macro-invertebrate communities four different indices were calculated for each sampling sites. The Shannon-Wiener Diversity Index $\left(\mathrm{H}^{\prime}\right)$ is a diversity index that incorporates richness and evenness. A high $\mathrm{H}^{\prime}$ indicates a good water quality. $\mathrm{H}^{\prime}$ was calculated as follows:

$\mathrm{H}^{\prime}=-\sum\left(\mathrm{P}_{\mathrm{i}} \ln \left[\mathrm{P}_{\mathrm{i}}\right]\right)$ Eqn ( 1)

Where: $P_{i}$ is the relative abundance $\left(n_{i} / N\right)$ of family $\mathrm{i}, \mathrm{n}_{\mathrm{i}}=$ number of individuals in 
family $\mathrm{i}$ and $\mathrm{N}=$ total number of individuals in all families. $\mathrm{H}^{\prime}$ is ranging from 0 for a community with a single family, to over 7 for a very diverse community.

The Hilsenhoff Family-level Biotic Index (HFBI) is a biotic index that is calculated by multiplying the number of individuals of each family by an assigned tolerance value for that family. Assigned tolerance values ranged from 0 to 10 for families and increase as water quality decreases (Hilsenhoff 1988; Bode et al., 1996). High HFBI community values are an indication of organic pollution, while low values indicate good water quality. This index was calculated as follows:

$\mathrm{HFBI}=\Sigma\left[\left(\mathrm{TV}_{\mathrm{i}}\right)\left(\mathrm{n}_{\mathrm{i}}\right)\right] / \mathrm{N} \ldots \ldots . . \mathrm{Eqn}(2)$

Where: $T V_{i}$ is tolerance value for family $i$, $n_{i}$ is the number of individuals in family $i$ and $\mathrm{N}$ is the total number of individual in the sample collection.

The percentage of Dipterans tends to increase with a decrease in water quality; they become increasingly dominant in terms of percent taxonomic composition and relative abundance along a gradient of increasing pollution (Ferrington, 1987; Plafkin et al., 1989). This index was calculated as follows:

$\%$ Dipterans $=100 *(\#$ Individual Dipterans / Total Individuals in sample).........Eqn( 3)

Family richness reflects the health of the community as a measurement of the variety of families present. Richness increases with increasing water quality, habitat diversity, and habitat suitability. This index was calculated as follows:

$\mathrm{FR}=\#$ the number of different family) of animals in the sample. Eqn (4)

Excel spreadsheets and statistical software (SPSS version 20) were used for the statistical analysis. One way ANOVA was used to evaluate differences in water quality data and aquatic macro invertebrate metrics among the sampling sites. Differences among means were tested using Tukey HSD.

\section{Results and Discussion Physico-chemical Parameters}

The mean values of dissolved oxygen that ranged from $2.4 \mathrm{mg} / \mathrm{l}$ at sampling site C5 to $7.5 \mathrm{mg} / \mathrm{l}$ at sampling site A showed significant variation among sampling sites $(\mathrm{F}=12.354, \mathrm{P}=0.000$, Table 1). A higher mean value of $\mathrm{DO}$ was recorded at sampling site of $\mathrm{C} 4$ than other canal sites could be due to the presence of dense Papyrus Cyprus and other plants at this site. The drastic decrease of dissolved oxygen mean values at sampling site C5 may be attributed to the added high organic pollutants from main campus of Bahir Dar University (Peda campus) students and staff cafeterias 'and toilets`. Study conducted by Prabu et al. (2008) also showed low dissolved oxygen value with mean value of $3.2 \mathrm{mg} / \mathrm{l}$ in sewage wastewater that discharges to Huluka River from Ambo town in Ethiopia.

The mean values of $\mathrm{BOD}_{5}$ ranged from $15.3 \mathrm{mg} / \mathrm{l}$ at sampling site A to $39.3 \mathrm{mg} / \mathrm{l}$ C5 .The mean value showed significant variation among sampling sites $(\mathrm{F}=$ 40.346, $\mathrm{P}=0.000$ ), the value at $\mathrm{C} 5$ being higher than at the other sites (Table 2). The high levels of $\mathrm{BOD}_{5}$ are the indicators of the toxic waste strength of the effluents (Yusuff and Sonibare, 2004; Geetha et al., 2008).

The $\mathrm{pH}$ mean values were 6.3 for $\mathrm{C} 2$ and 7.67 for $\mathrm{A}$. The mean values did not differ significantly among sampling sites $(\mathrm{F}=1.421, \quad \mathrm{P}=0.274) \quad$ (Table 2). The temperature mean values ranged from 17 ${ }^{0} \mathrm{C}$ at $\mathrm{C} 2$ to $24.27{ }^{0} \mathrm{C}$ at $\mathrm{R}$ and values differ significantly among sampling sites $(\mathrm{F}=5.744, \mathrm{P}=0.003$ ) (Table 2). The $\mathrm{pH}$ of sewage wastewater of Ambo town was 7.9 
and temperature was $15.2{ }^{\circ} \mathrm{C}$ (Prabu et al., 2008).

The mean values of TDS varied from $101.7 \mathrm{ppm}$ at sampling site A to $738.3 \mathrm{ppm}$ at $\mathrm{C} 5$, mean value showed significant variation $(\mathrm{F}=25.268, \mathrm{P}=0.000)$, the value at C5 being significantly higher than at other sites (Table 2). Study conducted at urban waste water of Addis Ababa showed mean value of TDS 328 ppm (Dagne , 2010) which is much lower than the TDS values found in the present study.

The mean values of conductivity ranged from $141 \mu \mathrm{S} / \mathrm{cm}$ at sampling site $\mathrm{A}$ to $1470 \mu \mathrm{S} / \mathrm{cm}$ for C5. There was significant variation among sampling sites $(\mathrm{F}=51.953, \quad \mathrm{P}=0.000)$; the value at $\mathrm{C} 5$ being significantly higher than other sites (Table 2).

The mean value of sulphate ranged from $7 \mathrm{mg} / 1$ at sampling site A to $25.7 \mathrm{mg} / 1$ at sampling site $\mathrm{C} 5$. The mean value did not show significant variation among sampling sites (Table 2). The mean values for phosphate ranged from $0.2 \mathrm{mg} / \mathrm{l}$ at sampling site (A and $\mathrm{R}$ ) to $2.6 \mathrm{mg} / \mathrm{l}$ at sampling site C5 and values did not significantly varied among sampling sites (Table 2).

Table 2: Mean $( \pm$ SE) values of water quality parameters of study sites

\begin{tabular}{lllllllll}
\hline Parameters & C1 & C2 & C3 & C4 & C5 & R & A & $\begin{array}{l}\text { P- } \\
\text { value }\end{array}$ \\
\hline DO $(\mathrm{mg} / \mathrm{l})$ & $4.9 \pm 1$ & $4.8 \pm 0.4$ & $4.8 \pm 0.4$ & $6.8 \pm 0.4$ & $2.4 \pm 0.3$ & $7.21 \pm 1$ & $7.5 \pm 0.4$ & .000 \\
BOD $_{5}(\mathrm{mg} / \mathrm{l})$ & $34.7 \pm 4$ & $37.0 \pm 4$ & $28.3 \pm 0.6$ & $19.0 \pm 0.6$ & $39.3 \pm 0.3$ & $18.17 \pm 1.9$ & $15.3 \pm 0.4$ & .000 \\
pH & $7.6 \pm 0.9$ & $6.3 \pm 0.1$ & $6.5 \pm 0.5$ & $6.8 \pm 0.5$ & $6.8 \pm 0.2$ & $7.67 \pm 0.4$ & $7.3 \pm 0.2$ & .274 \\
Temperature $\left({ }^{\circ} \mathrm{C}\right)$ & $21.2 \pm 1$ & $17.0 \pm 0.6$ & $21.7 \pm 1.2$ & $18.6 \pm 0.8$ & $20.7 \pm 1.7$ & $24.27 \pm 0.4$ & $23.6 \pm 1.3$ & .003 \\
TDS $(\mathrm{ppm})$ & $667 \pm 68.2$ & $656.7 \pm$ & $505.3 \pm$ & $473.3 \pm$ & $738.3 \pm$ & $129 \pm 14.8$ & $101.7 \pm 9.7$ & .000 \\
& & 35.9 & 43.6 & 97.6 & 27.1 & & & \\
Conductivity $(\mu \mathrm{S} /$ & $907.7 \pm$ & $968.3 \pm$ & $975.7 \pm$ & $858.7 \pm$ & $1470 \pm$ & $168 \pm 8.1$ & $141 \pm 36.1$ & .000 \\
cm & 42.2 & 15.9 & 12.6 & 20.5 & 162.7 & & & \\
Total & $218 \pm 24$ & $215 \pm 27.5$ & $225 \pm 13$ & $208 \pm 13.2$ & $227 \pm 20.3$ & $95 \pm 4.3$ & $84 \pm 3.5$ & .000 \\
Alkalinity $(\mathrm{mg} / \mathrm{l})$ & & & & & & & & \\
Total & $295 \pm 10.4$ & $238 \pm 21.3$ & $221 \pm 13.6$ & $187 \pm 17.4$ & $313 \pm 17.6$ & $110 \pm 15.5$ & $91 \pm 3.7$ & 0.28 \\
Hardness $(\mathrm{mg} / \mathrm{l})$ & & & & & & & & \\
So $_{4}{ }^{2-}(\mathrm{mg} / \mathrm{l})$ & $18.7 \pm 1.4$ & $17 \pm 1.3$ & $14.8 \pm 1.4$ & $18.7 \pm$ & $25.7 \pm 1.1$ & $9 \pm .6$ & $7 \pm .00$ & .911 \\
Po4 $^{3--(\mathrm{mg} / \mathrm{l})}$ & $2.2 \pm .6$ & $1.6 \pm .6$ & $1 \pm .2$ & $1.6 \pm .9$ & $2.6 \pm 1.8$ & $0.2 \pm .00$ & $0.2 \pm .00$ & .095 \\
\hline
\end{tabular}

As shown in Table 3, mean Value of $\mathrm{BOD}_{5}$ was above maximum allowable limits set by international finance corporation (IFC) Environmental, health, and safety guidelines and the standards for industrial and municipal wastewater discharges to surface water by Saudi Arabia adopted by the Presidency of Metrology and Environment (PME).

The mean value of conductivity was above maximum allowable limits set by South Africa standards. Moreover, mean value of phosphate was above maximum allowable limit set by Kingdom of Saudi Arabia standards for industrial and municipal wastewater discharges to surface water.

Discharging the effluents containing high $\mathrm{BOD}_{5}$, conductivity and phosphate in to receiving surface water may result in physiologically stressful conditions for sensitive aquatic organisms but, can create favorable condition for tolerant diseasecausing organisms.

Generally, the increment of pollutants going down through the open canal could be due to the inappropriate disposal of wastes from households, commercial centre's, public centers, garage and petrol stations and some parameters clearly 
showed that the waste water can have

around the study area.

effects both on aquatic life and human

Table 3: Characteristic of Bahir Dar municipal canal effluents joining the Head of Blue Nile River compared to guideline values of IFC (2007), KSA (2012) and SA (DWA) (2008)

\begin{tabular}{|c|c|c|c|c|c|c|}
\hline Parameter & Minimum & Maximum & Mean & IFC & KSA & SA(DWA) \\
\hline $\mathrm{DO}(\mathrm{mg} / \mathrm{l})$ & 3 & 7 & 5 & - & - & - \\
\hline $\mathrm{BOD}_{5}(\mathrm{mg} / \mathrm{l})$ & 17 & 42 & 31 & 30 & 10 & - \\
\hline $\mathrm{pH}(\mathrm{pH}$ Units $)$ & 5.87 & 8.70 & 6.81 & $6-9$ & $6.5-8.5$ & $5.5-7.5$ \\
\hline Temperature $\left({ }^{0} \mathrm{C}\right)$ & 16 & 24 & 19.8 & - & - & - \\
\hline TDS (ppm) & 316 & 796 & 608 & - & - & - \\
\hline Conductivity $(\mu \mathrm{S} / \mathrm{cm})$ & 823 & 1671 & 1036.1 & - & - & 150 \\
\hline Total Alkalinity(mg/l) & 180 & 269.80 & 218.5 & - & - & - \\
\hline Total Hardiness $(\mathrm{mg} / \mathrm{l})$ & 75 & 410 & 250.8 & - & - & - \\
\hline $\mathrm{So}_{4}{ }^{2-}(\mathrm{mg} / \mathrm{l})$ & .52 & 47 & 18.9 & - & 600 & - \\
\hline $\mathrm{Po}_{4}{ }^{3--}(\mathrm{mg} / \mathrm{l})$ & .20 & 4.50 & 1.8 & - & 1 & 2.5 \\
\hline
\end{tabular}

Even though, it was evident that local people grew vegetables and crops at sides of the canal using the waste water, mean values of $\mathrm{BOD}_{5}$, conductivity and total alkalinity indicates the wastewater from Bahir Dar municipal $(\mathrm{C} 1, \mathrm{C} 2, \mathrm{C} 3, \mathrm{C} 4$ and C5) are unfit for irrigation purposes. Moreover, people were using water from the River for drinking, bathing and livestock watering, mean values of $\mathrm{DO}, \mathrm{BOD}_{5}$ and total alkalinity from head of Blue Nile River (A and R) were lower than the WHO recommended values for drinking purpose (Table 4).

Table 4: Comparison of Mean values of municipal canal waste water with FAO (1995) standards water for irrigation and River water with WHO (2008) standards water for drinking purposes

\begin{tabular}{llllllllll}
\hline Parameter & C1 & C2 & C3 & C4 & C5 & FAO & R & A & WHO \\
\hline DO & 4.9 & 4.8 & 4.8 & 6.8 & 2.4 & 2 & 7.21 & 7.5 & $>10$ \\
$\mathrm{BOD}_{5}$ & 34.7 & 37.0 & 28.3 & 18.0 & 39.3 & 10 & 18.17 & 15.3 & $\leq 10$ \\
pH & 7.6 & 6.3 & 6.5 & 6.8 & 6.8 & $6.5-8.5$ & 7.67 & 7.3 & $6.5-9.2$ \\
Temperature & 21.2 & 17.0 & 21.7 & 18.6 & 20.7 & 25 & 24.27 & 23.6 & 30 \\
TDS & 667 & 656.7 & 505.3 & 473.3 & 738.3 & 2000 & 129 & 101.7 & 300 \\
Conductivity & 907.7 & 968.3 & 975.7 & 858.7 & 1470 & 350 & 168 & 141 & 250 \\
Total Alka. & 218 & 215 & 225 & 208 & 227 & 200 & 95 & 84 & $<75$ \\
Total Hard. & 295 & 238 & 221 & 187 & 313 & 350 & 110 & 91 & $<100$ \\
SO $_{4}$ & 18.7 & 17 & 14.8 & 18.7 & 25.7 & 20 & 9 & 7 & 20 \\
PO $_{4}$ & 2.2 & 1.6 & 1 & 1.6 & 2.6 & 3 & 0.2 & 0.2 & - \\
\hline
\end{tabular}

\section{Aquatic Macro Invertebrate Taxa}

A total of 30 families comprising 6813 individuals were collected from the six sites (C2, C3, C4, C5, A and R) during the study period. As shown in Table 5, the total number of family present at each site ranged from $11(\mathrm{C} 2)$ to $16(\mathrm{~A})$, while the total number of individuals present at each site ranged from $229(\mathrm{R})$ to $4916(\mathrm{C} 5)$. The major components of the community were Clucidae (4146), Chironomidae (594), Ephydiridae (444), Syrphridae (437), and Belestomatidae (202). The families least encountered were Dytiscidae (2) and Sciomonzydae (5). The aquatic macro invertebrate communities were dominated by the tolerant taxa dipterans; together they represented more than $84 \%$ of the observed 
individuals. The tolerant Culicidae (Dipterans) were the most dominant family. Sensitive taxa as Ephemeroptera, and Trichoptera represented together only $1.2 \%$ of the observed numbers, whereas Plecoptera were totally lacking. The opportunistic pollution tolerant aquatic macro invertebrate taxa recorded at these stations are known to thrive in organically polluted areas of aquatic environments. Furthermore, the total number of families (30) observed in the present study was comparable with Wosinie and Wondie (2014) but was rather low compared with other studies in Ethiopia (Mehari et al., 2014; Sitotaw, 2006) and in Africa (Kibichii et al., 2007; Kasangaki et al., 2008; Masese et al., 2009).

Table 5: Number of aquatic macro invertebrates collected from the study sites

\begin{tabular}{|c|c|c|c|c|c|c|c|c|c|}
\hline \multirow[t]{2}{*}{ Family/order } & \multirow[b]{2}{*}{ TV } & \multicolumn{8}{|c|}{ Sampling sites } \\
\hline & & $\mathrm{C} 1$ & $\mathrm{C} 2$ & C3 & $\mathrm{C} 4$ & $\mathrm{C} 5$ & $\mathrm{~A}$ & $\mathrm{R}$ & Total \\
\hline Acarina & & NA & & & & & & & \\
\hline Tetragnathidae & 4 & NA & 0 & 0 & 0 & 0 & 12 & 0 & 12 \\
\hline \multicolumn{10}{|l|}{ Dipterans } \\
\hline Ceratopogonidae & 6 & NA & 0 & 0 & 13 & 7 & 24 & 0 & 44 \\
\hline Chironomidae & 8 & NA & 160 & 67 & 40 & 309 & 13 & 5 & 594 \\
\hline Culicidae & 8 & NA & 49 & 141 & 51 & 3845 & 23 & 37 & 4146 \\
\hline Ephydiridae & 5 & NA & 37 & 0 & 31 & 374 & 0 & 2 & 444 \\
\hline Psychodidae & 6 & NA & 5 & 3 & 6 & 55 & 0 & 0 & 69 \\
\hline Sciomonzydae & 10 & NA & 0 & 0 & 0 & 5 & 0 & 0 & 5 \\
\hline Syrphridae & 8 & NA & 58 & 32 & 64 & 283 & 0 & 0 & 437 \\
\hline Tabanidae & 8 & NA & 0 & 5 & 0 & 6 & 0 & 0 & 11 \\
\hline \multicolumn{10}{|l|}{ Coleopteran } \\
\hline Dytiscidae & 5 & NA & 0 & 0 & 0 & 0 & 2 & 0 & 2 \\
\hline Elmidae & 5 & NA & 0 & 0 & 15 & 0 & 16 & 1 & 32 \\
\hline Halpilidae & 5 & NA & 0 & 0 & 20 & 0 & 0 & 0 & 20 \\
\hline Hydrophilidae & 5 & NA & 0 & 0 & 0 & 0 & 0 & 13 & 13 \\
\hline \multicolumn{10}{|l|}{ Hemiptera } \\
\hline Belestomatidae & 9 & NA & 60 & 13 & 17 & 9 & 49 & 54 & 202 \\
\hline Corixidae & 8 & NA & 0 & 13 & 10 & 0 & 0 & 0 & 23 \\
\hline Gerridae & 9 & NA & 0 & 27 & 0 & 0 & 0 & 13 & 40 \\
\hline Naucoridae & 6 & NA & 0 & 16 & 23 & 5 & 10 & 0 & 54 \\
\hline Nepidae & 7 & NA & 0 & 0 & 0 & 0 & 0 & 7 & 7 \\
\hline Notonectidae & 9 & NA & 0 & 0 & 0 & 3 & 20 & 0 & 23 \\
\hline Veliidae & 7 & NA & 23 & 0 & 7 & 0 & 94 & 0 & 124 \\
\hline \multicolumn{10}{|l|}{ Snails } \\
\hline Hydrobiidae & 8 & NA & 4 & 15 & 5 & 0 & 0 & 0 & 24 \\
\hline Physidae & 7 & NA & 13 & 20 & 0 & 9 & 24 & 12 & 78 \\
\hline Planorbidae & 7 & NA & 0 & 19 & 0 & 0 & 0 & 0 & 19 \\
\hline \multicolumn{10}{|c|}{ Odonata ( Damsel and Dragon) } \\
\hline Aeshnidae & 3 & NA & 0 & 0 & 0 & 0 & 30 & 12 & 42 \\
\hline Coenagriondae & 9 & NA & 12 & 30 & 25 & 3 & 29 & 58 & 157 \\
\hline Gomphidae & 9 & NA & 0 & 0 & 0 & 0 & 13 & 5 & 18 \\
\hline Libellulidae & 9 & NA & 48 & 38 & 4 & 0 & 0 & 0 & 90 \\
\hline \multicolumn{10}{|l|}{ Ephemeroptera } \\
\hline Baetidae & 5 & NA & 0 & 0 & 0 & 3 & 12 & 9 & 24 \\
\hline Caenidae & 6 & NA & 0 & 0 & 0 & 0 & 18 & 1 & 19 \\
\hline \multicolumn{10}{|l|}{ Trichoptera } \\
\hline Hydropsychidae & 4 & NA & 0 & 0 & 0 & 0 & 40 & 0 & 40 \\
\hline Total individual & & & 469 & 439 & 331 & 4916 & 429 & 229 & 6813 \\
\hline Total family & & & 11 & 14 & 15 & 14 & 16 & 14 & 30 \\
\hline
\end{tabular}

NA: not available 


\section{Aquatic Macro invertebrate Community Structure}

The mean value of $\mathrm{H}^{\prime}$ ranged from 0.78 at $\mathrm{C} 5$ indicating that it has been affected by pollutants to 2.3 at $\mathrm{A}$ having better diversity. The $\mathrm{H}^{\prime}$ value showed significant variation among sampling sites $(\mathrm{F}=$ 17.482, $\mathrm{P}=0.000)$; the value being significantly higher at $\mathrm{A}$ than other sampling sites (Table 6). The $\mathrm{H}^{\prime}$ value of less than 1 indicates highly polluted, 1-3 moderately polluted, and greater than 4 unpolluted water bodies (Wilhm and Dorris, 1968). In present study, sampling sites C2, C3, C4, R and A signify moderate pollution whereas, C5 indicates high pollution conditions.

The mean values for HFBI ranged from 8.11 at sampling site $\mathrm{C} 3$ to 6.67 at sampling site A. Differences among sampling sites were significant $(\mathrm{F}=$ 22.562, $\mathrm{P}=0.000$ ). The Hilsenhoff Family level biotic index was developed to detect organic pollution. In this study, all sites showed highest HFBI values; suggesting fairly poor (A and C4) and poor (C2, C3, $\mathrm{C} 5$ and $\mathrm{R}$ ) water quality conditions (Hilsenhoff, 1988).

Family richness ranged from 16 at sampling site A to 11 at sampling sites C2 (Table 6), differences among sampling sites were significant $(\mathrm{F}=5.907, \mathrm{P}=$ 0.006). Based on Plafkin (1989) criteria for Family richness, all sampling sites were moderately impacted and this might be due to the elimination of the sensitive taxa due to pollution.

The mean value for percent dipterans were high at sampling site C5 and values significantly varied among sampling sites $(F=4.94, P=.000)$ (Table 6). Since most dipterans larvae contain hemoglobin they are able to survive low oxygen conditions (Lake, 2003) and their higher abundance is indication of poor water quality (Masese $e t$ al., 2013).

Table 6: Mean values for Shannon wiener diversity index $\left(\mathrm{H}^{\prime}\right)$, Hilsenhoff Family biotic index ( HFBI), Taxa richness ( TR) and percents dipterans ( \% dipterans)

\begin{tabular}{lllllllll} 
& C1 & C2 & C3 & C4 & C5 & R & A & P-value \\
\cline { 2 - 8 } H' $^{\prime}$ & NA & 1.53 & 1.27 & 1.9 & 0.78 & 1.96 & 2.3 & .000 \\
HFBI & NA & 7.9 & 8.11 & 7.44 & 7.76 & 7.88 & 6.67 & .000 \\
TR & NA & 11 & 14 & 15 & 14 & 14 & 16 & .006 \\
$\%$ Dipterans & NA & 66 & 56 & 63 & 98 & 20 & 14 & .000 \\
\hline
\end{tabular}

\section{Conclusion}

Most water quality parameters of effluents were above acceptable levels set by international standards for effluents to be discharged to surface water and FAO maximum permissible level set for waste water to be used for irrigation purposes. Besides, some water quality parameters of the head of Blue Nile River were above WHO maximum permissible level set for drinking purposes. In addition, aquatic macro invertebrate's indexes showed deteriorated water quality conditions.
Therefore, to reverse the adverse outcomes of effluents, the Town Service Administration Office Authorities of Bahir Dar Town should develop municipal waste treatment plant or other mechanisms for treating wastes and minimizing their adverse effect on environment. Furthermore, Bahir Dar University which is one of the big public institutions in the country should develop institutional wastewater treatment plants and management systems that can be a model for other institutions in Bahir Dar town. 


\section{Acknowledgements}

This research was conducted with the help of a grant from Bahir Dar University for which we are grateful. We are thankful for the practical and mental support of colleagues and friends during the course of the research. We thank Dr. Koos (J.) Vijverberg for improving the manuscript.

\section{References}

Abay, B. (2007). Assessment of downstream pollution profiles of Awassa textile factory effluent along Tikur Wuha river using physicochemical and macro invertebrate indicators. M.Sc Thesis. School of Graduate Studies, Addis Ababa University.

Akalu, S. (2006). Assessing the biological integrity of the great Akaki river using macroinvertebrates. Addis Ababa University. M.Sc thesis, School of Graduate Studies, Addis Ababa University.

American Public Health Association (1998). Standard methods for the examination of water and wastewater. $20^{\text {th }}$ edition Washington, D.C.

Berhe, T. (1988). The Degradation of the Abo- Kebena river in Addis Ababa. Ethiopia. M.Sc Thesis, School of Graduates Studies, Addis Ababa University.

Bode, R.W., Novak, M.A. and Abele, L.E. (1996). Quality assurance work plan for Biological stream monitoring in New York State. NYS Department of Environmental Conservation, Albany, NY.

Bouchard, R.W. (2004). Guide to aquatic macroinvertebrates of the upper midwest. Water resources center,
University of Minnesota, St. Paul, MN.

CSA, (2007). Statistical Abstract, Central Statistical Agency, Addis Ababa.

Dagne, M. (2010). Performance evaluation of kality wastewater stabilization ponds for the treatment of Municipal sewage, from the city of Addis Ababa, Ethiopia. MSc thesis, School of Graduate Studies, Addis Ababa University.

Davis, S., Vellids, G. and Pringle, C.M. (2003). Macro invertebrates Biomonitoring in Interminant Coastal Plain Streams Impacted by Animal Agriculture, Journal of Environmental Quality, 32:10361043.

Edmondson, W.T, (1959). Fresh water biology. $2^{\text {nd }}$ ed. John Wiley and Sons Inc. New York, USA.

FAO (1995). Environmental impact assessment of irrigation and drainage projects. Irrigation and Drainage paper No.53.Food and Agriculture organization, Rome, Italy, $85 \mathrm{pp}$.

Ferrington, L.C. (1987). Collection and identification of floating exuviae of Chironomidae for use in studies of surface water quality. SOP No. FW 130A. U.S. Environmental protection agency, region VII, Kansas City, KS.

Geetha, A., Palanisamy, P.N., Sivakumar, P., Ganesh, P.K. and Sujatha, M. (2008). Assessment of underground water contamination and effect of textile effluents on Noyyal (9 river basin in and around Tiruppur town, Tamil Nadu). 4: 696-705

Gooderham, J. and Tysrlin, E. (2002). The water bug book. A guide to the freshwater macroinvertebrates of temperate Australia. Csiro publishing. 
Hilsenhoff, W.L. (1988). Rapidfield assessment of organic pollution with a family-level biotic index. J. North Am. Bentholog. Soc., 7: 65-68.

International Finance Corporation (World Bank Group), (2007). Environmental, health, and safety guidelines for textile manufacturing.

Jain, C.K. and Bhatia, K.K. (1987). In: Physicochemical analysis of water and waste water, Mannual UM-26; National Institute of Hydrology, Roorkee,

Jessup, B.K., Markowitz, A. and Stribling, J.B. (1999). Family-level key to the stream invertebrates of Maryland and surrounding areas. Maryland department of natural resources Chesapeake Bay and watershed program resource assessment service monitoring and non-tidal assessment division CBWP-MANTA-EA-99-2.

Kasangaki, A., Chapman, L.J. and Balirwa, J. (2008). Land use and the ecology of benthic macroinvertebrate assemblages of high-altitude rainforest streams in Uganda. Freshw. Biol., 53: 681-697.

Kibichii, S., Shivoga, W.A., Muchiri, M. and Miller, S.N. (2007). Macroinvertebrate assemblages along a land-use gradient in the upper River Njoro541 watershed of Lake Nakuru drainage basin, Kenya. Lakes Reserv.: Res. Manage. 12: 107-117.

Klemm, D.J., Lewis, P.A., Fulk, F. and Lazorchak, J.M. (1990). Macroinvertebrate field and laboratory methods for evaluating the biological integrity of surface waters. EPA/600/4-90/030. U.S. Environmental protection agency: Office of research and development, Washngton D.C.
Lake PS, (2003). Ecological effects of perturbation by drought in flowing waters. Freshw. Biol., 4: 1161-1172.

Mandaville, S.M. (2002). Benthic macroinvertebrates in freshwaters-taxa tolerance values, metrics, and protocols. Project H-1. Soil and Water conservation society of metro Halifax. Environmental protection agency: Office of research and development, Washington D.C. of water and wastewater. $20^{\text {th }}$ edition Washington, D.C.

Masese, F.O., Muchiri, M. and Raburu, P.O. (2009). Macroinvertebrate assemblages as biological indicators of water quality in the Moiben River, Kenya. Afr. J. Aquat. Sci., 34:15-26.

Masese, F.O., Omukoto, J.O. and Nyakeya, K. (2013). Biomonitoring as a pre- requisite for sustainable water resources: a review of current status, opportunities and challenges to scaling up in East Africa. Ecohydrol. Hydrobiol., 13: 173-191.

Mehari, A.K., Wondie, A., Mingist, M. and Vijverberg, J. (2014). Spatial and seasonal variation in the macroinvertebrates and physico-chemical parameters of the Enfranz Rive, Lake Tana. Ecohydrol. Hydrobiol., 14: 304-312.

Mekonnen, F.H. (2012). Liquid waste management, the case of Bahi Dar, Ethiopia. Ethiopian Journal of Health Development. 1: 49-53.

Misganaw, S. (2007). Assessment of the ecological impacts of floriculture industries using physico-chemical parameters and benthic macroinvertebretes metric index along Wedecha river, Debrezeit, Ethiopia.M.Sc Thesis. School of 
Graduate Studies, Addis Ababa University.

Plafkin, J.L., Barbour, M.T., Porter, K.D., Gross, S.K. and Hughes, R.M. (1989). Rapid bioassessment protocols for use in streams and rivers. Benthic macroinvertebrates and fish. EPA 440-4-89-00. U.S. Environmental protection agency; Office of water regulations and standards, Washington, D.C.

Prabu, P.C., Teklemariam, Z., Nigusse, T. and Rajeshkumar, S. (2008). Journal of Science and Technology Characterisation of sewage wastewater and assessment of downstream pollution along Huluka River of Ambo, Ethiopia, 2:298-307

Samuel, M., Wondimu, R. and Moens, L. (2007). Pollution status of Tinishu Akaki River and its tributaries (Ethiopia) evaluated using physicochemical parameters, major ions and nutrients. Bulletin of the Chemical Society of Ethiopia, 21: 13-22.

Sitotaw, B, (2006). Assessment of benthicmacroinvertebrate structures in relation to environmental degradation in some Ethiopian rivers. M.Sc Thesis, School of Graduate Studies, Addis Ababa University.

UNDP (2004). Urban Agriculture: Food, Jobs and Sustainable Cities. New
York: UNDP Urban Harvest Working Paper Series, Paper No. 1

UN-Water, (2009). World Water Day brochure,http://www.unwater.org/wo rldwaterday/downloads/wwd09broch ureenLOW.pdf.

Wastewater Discharge Standards for Kingdom of Saudi Arabia (KSA), (2012). General Standards for the Environment (specifically document number 1409-01) issued by the Presidency of Meteorology and Environment (PME)Wilhm JL and Dorris TC, (1968). Biological parameters of water quality criteria. Bioscience; 18:477-481.

World Health Organization (WHO) (2008). International standard for drinking water quality, World Health Organization, Geneva, 2008.

Wosnie, A. and Wondie, A. (2014). Assessment of downstream impact of Bahir Dar tannery effluent on the head of Blue Nile River using macroinvertebrates as bioindicators," International Journal of Biodiversity and Conservation, 6: 342-350.

Yusuff, R.O. and Sonobare, A.J. (2004). Characterisation of textile Industries effluents in Kaduna, Nigeria and pollution implications. Global Nest the International Journal, 6:211-220. 